\begin{tabular}{rr} 
çağdaş & Yaratıcı Drama Dergisi 2016, 11(2), 65-82 \\
drama & www.yader.org \\
\hline
\end{tabular}

\title{
İlkokul Öğrencilerinin Sözvarlığını Geliştirmede Yaratıcı Drama Yönteminin Etkisi
}

\author{
Özge Metinnam ${ }^{1}$ \\ Tolga Erdoğan ${ }^{2}$
}

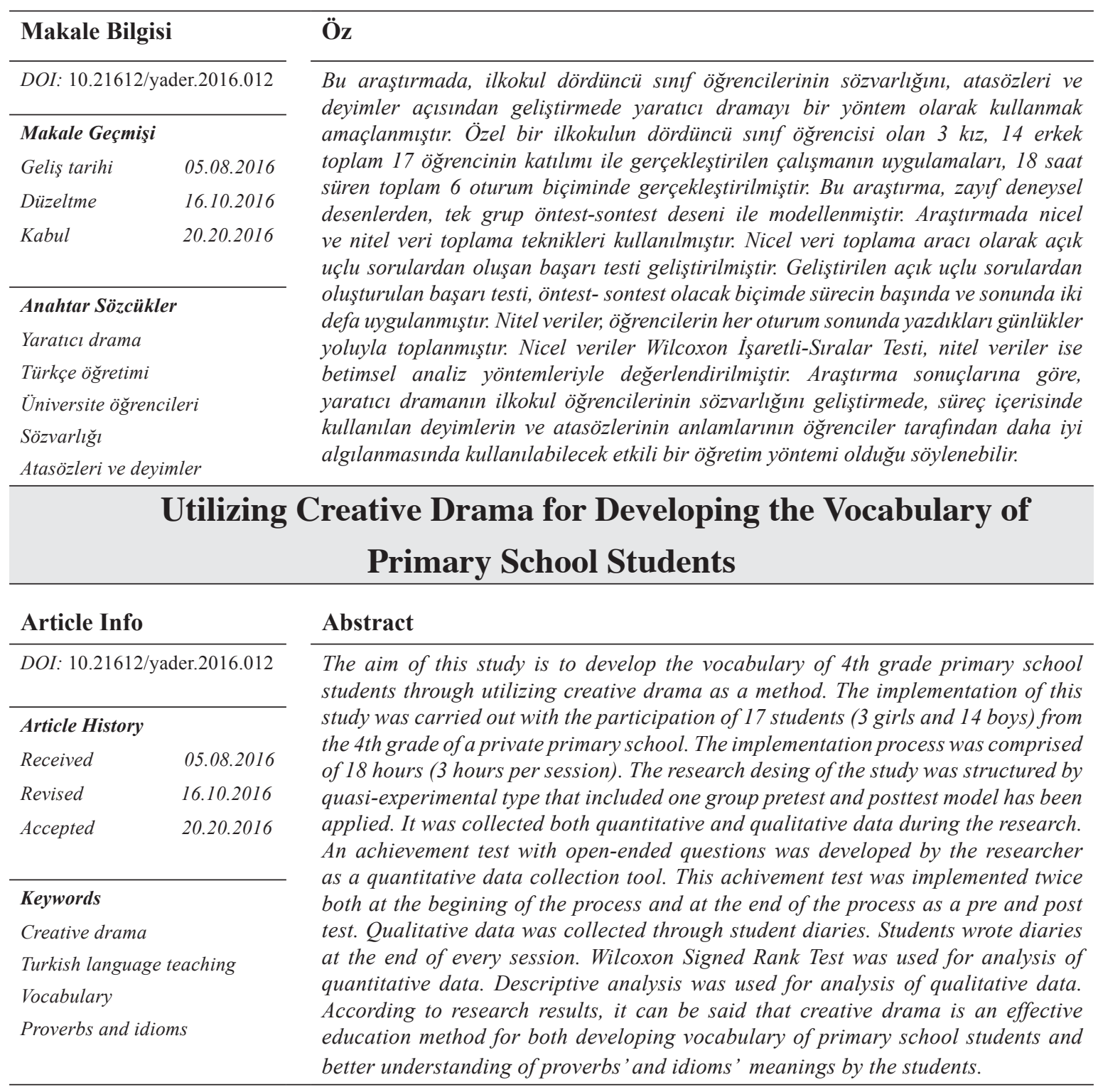

ODTÜ GVO Sınıf Öğretmeni, ozgemetinnam@gmail.com

2 Doç. Dr. KTÜ Fatih Eğitim Fakültesi Öğretim Üyesi, tolgaerdogan.edu@gmail.com 


\section{Giriş}

Türkçe öğretiminin temel amacı, dilini güzel ve doğru kullanabilen, düşünme becerilerine sahip ve okuma kültürü edinmiş bireyler yetiştirmektir. Bu temel amaç kapsamında Türkçe anlama ve anlatma becerilerinin geliştirilmesi önem kazanmaktadır. Dilsel beceriler olarak da adlandırılan 'dinleme', 'konuşma', 'okuma' ve 'yazma' becerilerinin çocuklara kazandırılması ve geliştirilmesi gerekir. Bu becerilerin kazandırılmasında en önemli öge çocukların söz varlığıdır.

Dil becerilerinin geliştirilmesi ile söz varlığı arasında yakın bir ilişki vardır (Demirci ve Baş, 2016). Anlama ve anlatmanın gerçekleşebilmesi için bireyin öncelikle yeterli sayıda sözcük bilmesi, söz varlığının belirli ölçüde gelişmiş olması gerekmektedir. Ana dilinin söz varlığını yeterli düzeyde öğrenmemiş bir öğrencinin akademik ya da sosyal alanda başarılı olması beklenemez (Yaşar ve Ünal, 2016).

Bir dilin sözvarlığını, yalnızca o dilin sözcükleri değil, deyimleri, kalıp sözleri, atasözleri, terimleri ve çeşitli anlatım kalıpları oluşturmaktadır. Sözvarlığı sadece bir dilde birtakım seslerin bir araya gelmesiyle kurulmuş simgeler, kodlar olarak değil, aynı zamanda o dili konuşan toplumun maddi ve manevi kültürünün yansıtıcısı olarak düşünülmelidir (Mert, 2009). Sözvarlığı içinde, bir dilin kendi ögelerinden oluşan, kimi zaman yabancı ögelerin de girdiği temel sözvarlığı, insanın organlarından ve vücut bölümlerinden başlayarak yiyecek-içeceklerine, en sık kullandıkları araçgereçlere, doğayla, tarımla ilgili konu ve olaylara, en sık gereksinme duydukları eylemlere ve sayı sistemine kadar uzanan bir kavramlar bütününü kapsar (Aksan, 2006).

$\mathrm{Bu}$ kavramlar bütününün içerisinde kalıplaşmış sözler, ikilemeler, terimler, deyimler ve atasözleri yer almaktadır. Sözvarlığı içerisinde yer alan deyimler ve atasözlerinin çok katmanlı anlam yapılarıyla toplumun dile yansıyan kültürünün izlerini taşıdığı, mecazlı söyleyişleriyle estetik bir yönlerinin de bulunduğu söylenebilir. Bu kültür, Orhun ve Yenisey yazıtlarından Türkiye Türkçesine kadar uzanmaktadır. Aksan'a (2006) göre; “bugün canlılığını koruyan atasözlerimizin 2000 dolayında olduğu ve deyimlerimizin ise günden güne yenileri eklenerek 7000 dolaylarına eriştiği düşünülmektedir".

Türk halk kültürünün önemli yapı taşı olan atasözleri ve deyimlerin Türkçe sözvarlığında önemli bir yere sahip olduğu söylenebilir. Deyim ve atasözlerini yerli yerinde kullanmak, bir dili iyi konuşup iyi yazabilmek için şarttır (Bağc1, 2010). Bu bağlamda anadilindeki deyimlerin ve atasözlerinin zenginliğinin farkına varan bir çocuk, dilini etkili bir şekilde kullanacak, kültürüne, diline yabancılaşmayacak, Türkçe’nin zengin bir dil olduğu bilincine varacaktır.

Öğrencilerin söz varlıklarını geliştirmede Türkçe öğretiminin amaçlarına ve ilkelerine uygun yöntem ve tekniklerin kullanılması gerekmektedir. Bu bağlamda, öğrencileri merkeze alan, yaparak ve yaşayarak öğrenme ile dil becerilerinin etkili bir şekilde geliştirilmesini sağlayan yöntemlerin kullanılması yerinde olacaktır. Bu yöntemlerden biri yaratıcı dramadır.

Yaratıcı drama, bir grupla, gruptaki katılımcıların yaşantılarından yola çıkarak, dramanın tekniklerini kullanma yoluyla oyunsu süreçlerde canlandırmalar yapmaktır (Adıgüzel, 2013). Yaratıcı drama, öğrenmek, sahneye çıkmadan ve oyunda rol yapmadan yaşam deneyimini genişletmek demektir (Heathcote, 1984). San'a (2002) göre yaratıcı drama doğaçlama, rol oynama vb. tiyatro ya da drama tekniklerinden yararlanılarak, bir grup çalışması içinde, bireylerin bir yaşantıyı, bir olayı, bir fikri, kimi zaman bir soyut kavramı ya da bir davranışı, eski bilişsel örüntülerin yeniden 
düzenlenmesi yoluyla ve gözlem, deneyim, duygu ve yaşantıların gözden geçirildiği "oyunsu" süreçlerde anlamlandırılması, canlandırılmasıdır.

Türkçe öğretimi ve yaratıcı dramanın genel amaçları incelendiğinde bu amaçların birbirleriyle örtüştüğ̈̈ görülmektedir. Yaratıcı dramaya ilişkin araştırmalara bakıldığında Türkçenin öğrenme alanlarına dönük uygulamalı ve canlandırmaya dayalı çalışmalar yapıldığı görülmektedir.

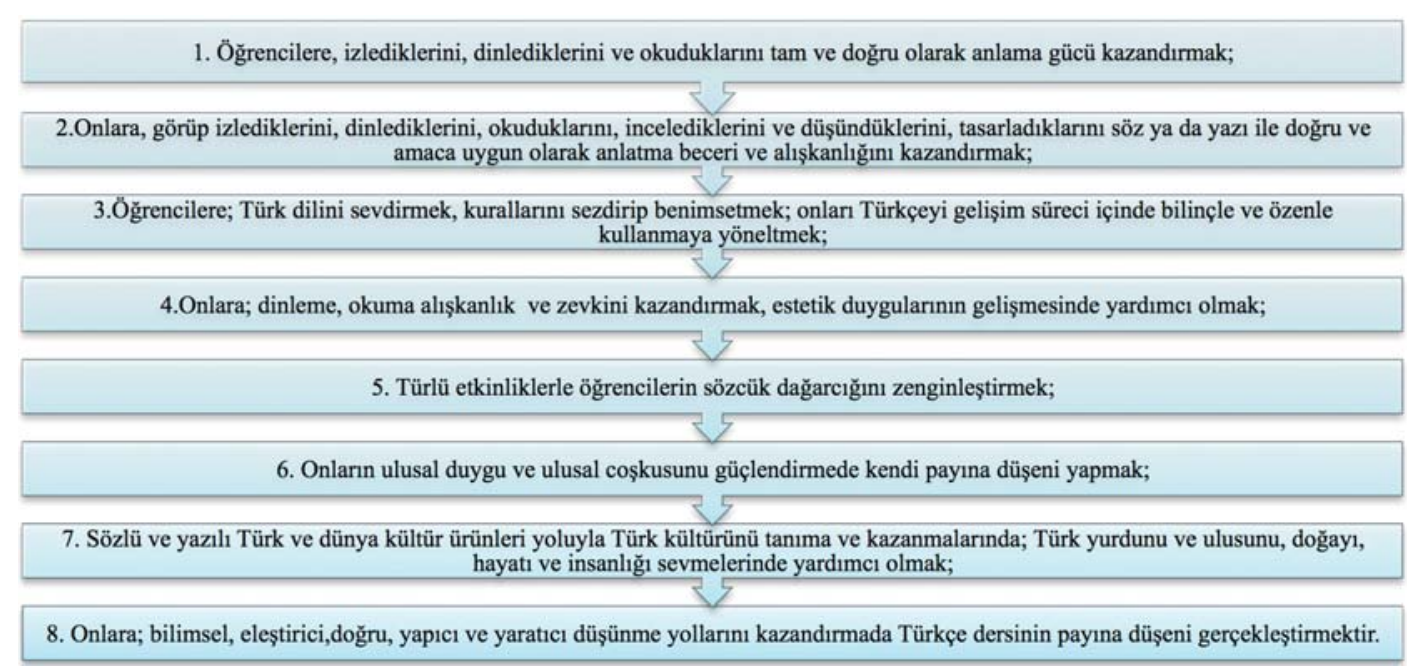

İlköğretim okulları Türkçe Eğitim Programında “Türkçe Eğitiminin Genel Amaçları”na (Sever, 2011) bakıldığında, aşağıda sıralanmış olan yaratıcı dramanın genel amaçlarıyla büyük ölçüde örtüştüğü görülebilir.

\begin{tabular}{|c|}
\hline 1. Yaratıcılı̆̆ ve Düş Gücünü Geliştirmek \\
\hline 2. Kendini Tanıma, Gerçekleştirme ve Başkalarıyla fletiş̧im Becerisini Geliştirmek \\
\hline 3.Demokratik Tutum ve Davranış Geliştirme \\
\hline 4. Estetik Davranışlar Geliştirme \\
\hline 5. Eleştirel ve Bağımsız Düşünebilme Becerisi Geliştirme \\
\hline 6. Iş Birliği Yapabilme- Birlikte Çalışma Becerisi Geliştirme \\
\hline 7. Sosyal Duyarlık Yaratma \\
\hline 8. Duygunun Sağlıklı Bir Biçimde Boşalımı ve Kontrolü \\
\hline 9. Dil Gelişimi, Sözel ve Sözel Olmayan Ifade Becerisini Geliştirme \\
\hline
\end{tabular}

"Yaratıcı dramanın sağladığı bazı temel amaçlar" (Adıgüzel, 2013).

Yaratıcı dramanın konusu her şey olabilir. Yaratıcı dramanın, Türkçe öğretimiyle örtüştürülebilecek ve Türkçe öğretimi sürecinde işe koşulabilecek yanlarından birisi ele alınan konunun niteliğine bakılmaksızın sanatsal ve estetik bir deneyime dönüşebilmesidir. Yaratıcı drama dinleme becerisine olumlu katk1 yapabileceği gibi dilin varsıl olanaklarını kavrayabilecek, estetik duyarlığa sahip sorgulayan bireylerin yetişmesine de katkı sağlayabilir. Ezberci eğitimin yol açtığ tıkanmalara karşılık, imgeleme ve tasarlama, sorun çözme, üretken olma aşamalarına götürebilecek bir eğitim, yaratıcı drama eğitimiyle kesinlikle sağlanabilir (San, 2010). 
Kavcar'ın (1999) genel olarak eğitim sistemine ilişkin önerdikleri de yaratıcı dramanın Türkçe dersinde bir öğretim yöntemi olarak kullanılmasının etkili sonuçlar vereceğini vurgular gibidir: "Bir eğitim sistemi, bireyi bilgi ve beceriyle donatma yanında çevreye uyum sağlama, çevreyi değiştirme, toplumun kültürel değerlerini aktarma ve geliştirme amaçlarına yöneliktir. Bütün bunları tiyatro, ders anlatma biçiminde değil, hemen tüm duyu organlarını harekete geçirerek, estetik yoluyla verir. Asıl gücü buradan gelmektedir".

Yaratıcı drama yönteminin kullanıldığı öğrenme ortamında, yaratıcı, üretken, yalnız, belli somut ürünler vererek değil, fikirde de üretken olabilen, yaratıcı kararlar verebilen, değişik olmaktan ve değişiklik yapmaktan korkmayan, çekinmeyen, dilini iyi kullanan, eleştirel ve yargılayıcı olabilen, dogmalara körü körüne bağlı kalmayan, dogmaları, tabuları tartışabilen gençler yetiştirmek mümkün olabilmektedir (San, 2006).

"Yaratıcı dramanın genel amacı, çocukların, ergenlerin ve gençlerin canlandırmalar yoluyla gerçek dünya ile kurgusal dünya arasında gidip gelmelerini olanaklı kılarak, bir bilinçlenme ve kültürlenme süreci içerisinde, her alanda yaratıcı, kendine yetebilen, kendini tanıyan, çevresiyle iletişim kurabilen ve bunu geliştirebilen, ifade gücü ve biçimleri artmış, imgesel düşünebilen, estetik kaygı, demokratik tutum ve davranışları gelişmiş bireyler yetiştirmektir” (Adıgüzel, 2013).

"Yaratıcı dramanın özellikleri, çok yönlü zekâya dönük uygulamalardaki işlevselliği nedeniyle sınıf dışındaki amaçlara uygun her türlü ortamlarda yaşantılara dayalı öğrenmeyi de gerçekleştirmede etkili bir yöntem ve disiplindir” (Adıgüzel, 2010). Bu bağlamda, yaratıcı drama Türkçe öğretiminin sorunlarından biri olarak gösterilen fiziksel olanaksızlıktan etkilenmez. $\mathrm{Bu}$ yönüyle, sınıfta uygulanabilecek etkili bir yöntem olarak gösterilebilir.

"Eğitimde yaratıcı dramayı yöntemsel olarak düşündügümüzde, eğitim ortamında değişik konuları öğretmek gibi bir amacı olduğunu da unutmamak gerekir. Çocukların ve ergenlerin ilgilerini genişletmek, gerçekliğe imgeleme aracılığı ile bakabilmeleri ve ulaşabilmelerini, onların oynamaktan çok anlamalarını sağlamak bu amacın içerisinde yer alır. Özetle yaratıcı drama kişinin, kendi bedenine, duygularına, düşüncelerine ve çevresinde olup bitenlere karşı bilinçli olmasını sağlar.” (Adıgüzel, 2010)

"Son yıllarda yapılan çalışmalar göstermiştir ki yaratıcı drama dil becerilerini geliştirmede en etkili yöntemlerden birisidir. Yaratıcı dramanın özündeki özgürlük, insanın tabiatındaki yaratıcılığı ortaya çıkarması açısından önemlidir" (Karateke, 2006). Yaratıcı drama çalışmalarında katılımcılar hangi yaş grubundan olurlarsa olsunlar, yaratıcı oyunlarla önemli değerler kazanırlar; hayal gücünü geliştirmeyi, bağımsız düşünebilmeyi, işbirliği yapabilmeyi, sosyal duyarlılık yaratmayı, duygunun sağlıklı bir biçimde boşalımını ve kontrolünü, dil gelişimi ve daha iyi konuşma alışkanlığını bu değerler arasında sayabiliriz (Adıgüzel, 2006).

Çocuklar, yaratıcı drama sürecinde konuşurlar, hareket ederler, bedenlerini, seslerini, duygularını, düşüncelerini kullanırlar, başkalarıyla iletişim halinde olurlar, kendi kendilerine kalarak düşünme olanağı bulurlar, özgün düşünce, davranış ve somut ürün oluştururlar, simgeler kullanırlar, hayal kurarlar eğlenir ve mutlu olurlar (Tuğrul, 2005).

Yaratıcı drama, öğretim programının eşsiz ve bütünleyici bir unsurudur. Eğitimde sistemli ve devamlı yaratıcı drama eğitimi vermek, öğrencilere değerlendirme, yaratma, keşfetme, çözümlemeye yönelik soru sorabilme becerilerine sahip olma şansı sağlar. Yaratıcı dramada bütün öğrenciler katılma hakkına sahiptir. Bu sayede deneyim ve cesaretleri gelişir (Gönen, 2010). 
Sonuç olarak, katılımcıların yaşantılarından yani yaşam gerçekliğinden yola çıkarak, katılımcıları sürekli devinim halinde tutan, estetik bir deneyim süreci olan yaratıcı dramanın, dil ve sözvarlığı gelişimi için kullanılabilecek etkili yöntemlerden biri olduğu söylenebilir. Yapılan araştırmalar da yaratıcı drama yönteminin öğrencilerin dil becerilerini geliştirmede etkili olduğunu ortaya koymaktadır (Aktaş Arnas, Cömertpay ve Sofu, 2007; Aykaç, 2011; Erdoğan, 2013; Karateke, 2006; Kaya Güler, 2008; Kırmız1, 2008; Stowe, 2001).

\section{Araştırmanın Amacı}

Araştırmanın amacı, ilkokul dördüncü sınıf öğrencilerinin sözvarlığını, atasözleri ve deyimler açısından geliştirmede yaratıcı dramanın bir yöntem olarak etkili olup olmadığını ortaya koymaktır.

\section{Yöntem}

\section{Araştırmanın Modeli}

$\mathrm{Bu}$ araştırma, zayıf deneysel desenlerden, tek grup öntest-sontest deseniyle modellenmiştir. $\mathrm{Bu}$ desende deneysel işlemin etkisi tek bir grup üzerinden yapılan çalışmayla test edilir. Deneklerin bağımlı değişkene ilişkin ölçümleri uygulama öncesinde öntest, sonrasında sontest olarak aynı denekler ve aynı ölçme araçları kullanılarak elde edilir (Büyüköztürk ve diğerleri, 2008).

Araştırmada nicel ve nitel veri toplama teknikleri kullanılarak veri toplanmıştır. Bunun amac1, veri çeşitlemesi (triangulation) yapmaktır. Bu kavramın öncülerinden olan Denzin (1994:6461'den akt; Türnüklü, 2001) "triangulation” kavramını şöyle açıklamaktadır: "Aynı olgunun incelenmesinde çeşitli araştırma yöntemlerinin uygulanması ve kaynaşmasıdır." "Triangulation” yapılan eğitimbilim çalışmasında çeşitli yöntem ve ölçümlerinin çalışma içerisinde birleşimine ve uyumuna işaret eder. Aynı zamanda tek bir yöntemin kullanılmasından kaynaklanabilecek sınırlılıkları ve yanlılıkları ortadan kaldırmak için aynı çalışmada farklı yöntem ve tekniklerin bir arada kullanımı anlamına da gelmektedir (Denzin, 1994'den akt; Türnüklü, 2001). Farklı tekniklerle veri toplanmasının amacı nicel verilerin nitel verileler desteklenerek, tek bir tekniğin kullanılmasından kaynaklanabilecek sınırlılıkları ve yanlılıkları ortadan kaldırmaktır.

\section{Çalışma Grubu}

Çalışma grubu, özel bir ilkokulun dördüncü sınıf öğrencisi olan ve haftada bir saat yaratıcı drama dersi alan 3 kız, 14 erkek toplam 17 öğrenciden oluşmaktadır.

\section{İşlem}

$\mathrm{Bu}$ araştırma, Çağdaş Drama Derneği’nin liderlik/eğitmenlik programı proje aşaması kapsamında yapılmıştır. Araştırma, Ankara'da özel bir ilkokulda öğrenim görmekte olan 3'ü kız, 14'ü erkek toplamda 17 öğrenciden oluşan dördüncü sınıf öğrencilerine uygulanmıştır. Araştırma süreci; Çağdaş Drama Derneği'ne dilekçenin verilmesi, alanyazın taraması, katılımcı grubun oluşturulması, çalışma mekânının, araç-gereçlerin sağlanması, atölye planlarının hazırlanması, atölye planlarının danışmanla geliştirilmesi ve düzeltilmesi, araştırmanın uygulanması, araştırma sonuçlarının değerlendirilmesi ve araştırmanın raporlaştırılması şeklinde basamaklara ayrılarak uygulanmıştır. Bu süreç 11.02.2014- 19.05.2014 tarihleri arasında tamamlanmıştır. 
$\mathrm{Bu}$ sürecin uygulama kısmı 6 oturumda toplam 18 saatte gerçekleştirilmiştir. Uygulama sürecinde atasözleri ve deyimlerin tercih edilmesinin nedeni, öğrencilerin bu söz varlıklarını günlük yaşamın dil çevrimi içerisinde bilmece, tekerleme gibi sözvarlığı ögelerine oranla daha sık kullanabileceklerinin düşünülmesidir.

Altı oturumun ilk üçünde belirlenen deyimlere son üçünde de belirlenen atasözlerine yer verilmiştir. Süreçte 15 deyim ve 10 atasözü kullanılmıştır. Atölyelerde kullanılan atasözleri ve deyimler, somut işlemler döneminde olan öğrenciler için soyut kalabileceği düşünülen, yaratıcı drama yöntemiyle somutlaştırılabilecek deyim ve atasözlerinden seçilmiştir. Bunun yanında, araştırmacının zaman ve kaynak sınırlılığının başka bir grupla çalışmaya izin vermemesinden dolayı tek grupla çalışılmıştır. Bu durum da araştırma deseninin belirlenmesinde etkili olmuştur. Çalışma yarı-deneysel desenle yürütülmüş olup, öğrenci başarısını ölçmeye dönük açık uçlu sorulardan oluşan bir sınav geliştirilmiştir.

\section{Veri Toplama Araçları}

\section{Nicel Veri Toplama Araçları}

Araştırmanın nicel veri toplama aracı olarak, yirmi beş açık uçlu sorudan oluşturulmuş bir açık uçlu sorulardan oluşturulan başarı testi kullanılmıştır. Bu açık uçlu sorulardan oluşturulan başarı testi, yaratıcı drama uygulamasının öğrencilerin sözvarlığının geliştirilmesine yönelik bir etkisinin olup olmadığının belirlenmesi amacıyla oluşturulmuştur. İçerik olarak, yaratıcı drama uygulama sürecinde kullanılan yirmi beş atasözü ve deyimi kapsayan sınav, öğrencilerin sürecin başından sonuna kadar gördükleri atasözleri ve deyimlerden kaç tanesini tanımlayabildiklerini ortaya koymaya dönük geliştirilmiştir. Açık uçlu sorulardan oluşturulan açık uçlu sorulardan oluşturulan başarı testi kapsam geçerliğini belirlemek amacıyla üç ayrı uzmanın değerlendirmelerine başvurulmuş, uzmanların değerlendirmeleri sonucu sınava son hali verilmiştir.

Öğrencilerin yanıtları, oluşturulan derecelendirme anahtarına göre puanlanmıştır. Bu derecelendirme anahtarı için üç ayrı uzmanın değerlendirmelerine başvurulmuştur. Açık uçlu soruların yer aldığı açık uçlu sorulardan oluşturulan başarı testinde her sorunun tam yanıtına 4 puan verilmiştir. Verilen yanıtlarda belirlenen deyimlerin ve atasözlerinin anlamlarını örnekle açıklayabilen ya da anlamını yazabilen öğrencilere tam puan verilmiştir. Cümle içerisinde deyimi ve atasözünü yanlış kullanan ve açıklayan öğrencilere 0 puan verilmiştir. Bir cümlede kullanan ancak açıklamasını yazamayan öğrencilere 2 puan verilmiştir. Derecelendirme anahtarı aşağıdaki tabloda gösterilmiştir:

Tablo 1. Derecelendirme Anahtarl

\begin{tabular}{|l|l|l|l|l|l|l|l|l|l|l|l|l|l|l|l|l|l|l|l|l|l|l|l|l|l|}
\hline 1 & 2 & 3 & 4 & 5 & 6 & 7 & 8 & 9 & 10 & 11 & 12 & 13 & 14 & 15 & 16 & 17 & 18 & 19 & 20 & 21 & 22 & 23 & 24 & 25 & Toplam \\
\hline 4 & 4 & 4 & 4 & 4 & 4 & 4 & 4 & 4 & 4 & 4 & 4 & 4 & 4 & 4 & 4 & 4 & 4 & 4 & 4 & 4 & 4 & 4 & 4 & 4 & 100 \\
\hline
\end{tabular}

\section{Nitel Veri Toplama Araçları}

Nitel veri toplama aracı olarak öğrencilerin her oturum sonunda yazdıkları günlüklerden yararlanılmıştır. Öğrencilerden her oturumun sonunda, duygularına, düşüncelerine ve o oturumda ele alınan içeriğe (atasözleri ve deyimler) ilişkin günlük yazmaları istenmiştir. Günlükler, tüm oturumların sonunda düzenli bir biçimde toplanmıştır. 


\section{Verilerin Analizi}

\section{Nicel Verilerin Analizi}

Açık uçlu sorulardan oluşturulan başarı testi, bütün katılımcılara programın ilk ve son oturumunda uygulanmıştır. Katılımcıların açık uçlu sorulardan oluşturulan başarı testi sorularına vermiş oldukları yanıtlar yüz (100) üzerinden değerlendirilmiş, aldıkları puanlar ön-test ve sontest puanları olarak belirlenmiştir. Başarı puanlarıyla ilgili veriler Wilcoxon işaretli-sıralar testi kullanılarak çözümlenmiştir. Wilcoxon işaretli-sıralar testi aynı denekler üzerinde iki farklı zamanda yapılan ölçümlerden elde edilen puanların değerlendirilmesinde, herhangi bir becerinin geliştirilmesinde kullanılmak amacıyla hazırlanan X programının etkililiğinin araştırılmasında kullanılabilir (Büyüköztürk, 2005).

Veri analizinin odak noktası başarı testindeki ön test ve son test puanları arasında anlamlı bir fark olup olmadığının belirlenmesi olmuştur.

Tablo 2. Tek Grup Öntest-Sontest Deseninin Simgesel Gösterimi (Büyüköztürk ve diğerleri, 2008).

\begin{tabular}{|c|c|c|c|}
\hline Grup & Öntest & İşlem & Sontest \\
\hline $\mathrm{G}$ & $\mathrm{O} 1$ & $\mathrm{X}$ & $\mathrm{O} 2$ \\
\hline
\end{tabular}

\section{Nitel Verilerin Analizi}

Üçer saatlik altı oturuma bölünmüş, toplamda on sekiz saatlik bir uygulamayı içeren araştırma sürecinde, her oturum sonunda öğrencilerden günlükler toplanmıştır. Bu günlükler, öğrencilerin tek tek her oturuma ve o oturumda işlenen atasözü ve deyimlere ilişkin değerlendirmelerini içermektedir. Günlükler, her atölyenin sonunda tutulmuş olup, öğrencilerin sürece ilişkin akıllarında kalanları yazdıkları açık uçlu metinler olarak tanımlanabilir.

Nitel veri toplama aracı olarak yararlanılan öğrenci günlükleri dört aşamada analiz edilmiştir: (1) verilerin kodlanması, (2) temaların bulunması, (3) kodların ve temaların bulunması, (4) bulguların tanımlanması ve yorumlanması (Yıldırım \& Şimşek, 2013). Nitel veri analizinden elde edilen bulgular, nicel veri analizinden elde edilen bulguları yordama ve yorumlama amacıyla kullanılmıştır.

\section{Bulgular}

Bu bölümde açı uçlu sorulardan oluşturulan başarı testine verilen yanıtlardan ve günlüklerden elde edilen verilerle ilgili bulgular ve yorumlar sunulmuştur.

\section{Nicel Verilerin Analizi}

Başarı testinin açık uçlu maddeleri dereceli puanlama anahtarı kullanılarak puanlanmış ve bu maddelerin ön test-son test puanlarının ölçümü için Wilcoxon işaretli sıralar testi kullanılmıştır.

Tablo 3. Katılımcıların Ön Test ve Son Test Puanlarının Wilcoxon İşaretli Sıralar Testi Sonuçları

\begin{tabular}{cccccc}
\hline (Son test-Ön test) & $\mathbf{n}$ & Sıra ortalaması & Sıra toplamı & $\mathbf{z}$ & $\mathbf{p}$ \\
\hline Negatif Sıra & 0 & .00 & .00 & $3.41^{*}$ & .001 \\
Pozitif Sıra & 15 & 8.00 & 120.00 & & \\
Eşit & 0 & - & - & & \\
\hline
\end{tabular}


Öğrencilerin deney öncesi ve sonrası sözvarlıkları gelişiminin anlamlı bir farklılık gösterip göstermediğine ilişkin Wilcoxon işaretli sıralar testi sonuçları Tablo:1'de verilmişsir. Analiz sonuçları araştırmaya katılan çocukların sözvarlığı başarı testinden aldıkları deney öncesi ve sonrası puanları arasında anlamlı bir fark olduğunu göstermektedir. $(\mathrm{z}=3.41, \mathrm{p}<.05-.05<.001)$. Fark puanlarının sıra ortalaması ve toplamları dikkate alındığında, gözlenen bu farkın pozitif sıralar, yani son test puanı lehinde olduğu görülmektedir. Bu sonuçlara göre, yaratıcı drama yöntemiyle düzenlenen sürecin çocukların sözvarlıklarını geliştirmede önemli bir etkisi olduğu söylenebilir.

\section{Nitel Verilerin Analizi}

Nitel araştırma verileri dört aşamada analiz edilir: (1) verilerin kodlanması, (2) temaların bulunmas1, (3) kodların ve temaların bulunmas1, (4) bulguların tanımlanmas1 ve yorumlanmas1 (Yıldırım \& Şimşek, 2013, s.260).

Günlük yoluyla elde edilen nitel verilerin analizi aşama aşama gerçekleştirilmiştir. Toplanan veriler dört aşamada analiz edilmiştir:

1. Günlükler okunarak veriler şu şekilde kodlanmıştır; “atasözü”, “oyunlar”, “deyimler", "resim yapma”, "canlandırma”, "rol oynama”, "atölye”, "eğlenmek”, "grup olma", "şarkı besteleme".

2. Kodlanan verilerden yola çıkılarak oluşturulan temalar şu şekildedir; "Öğrendiği Deyimleri Yazanlar", "Öğrendiği Deyimleri Anlamlarıyla Birlikte Yazanlar”, “Öğrendiği Atasözünü Yazanlar", "Öğrendiği Atasözü ve Deyimleri Yazanlar”, "Yaratıc1 Drama Sürecindeki Etkinliklerden Söz Edenler", "Yaratıcı Drama Sürecine İlişkin Tutumlarından Söz Edenler".

3. Kodlar ortak yönleri gözetilerek ilgili temaların altında toplanarak düzenlenmiştir.

4. Bulgular, kodlar ve temalara göre betimlenmiş, öğrencilerin yazdıkları günlüklerden yapılan doğrudan alıntılara yer verilerek örneklendirilmiş, açıklanmış, görselleştirilerek yorumlanmıştır. 
İlkokul Öğrencilerinin Sözvarlığını Geliştirmede Yaratıcı Drama Yönteminin Etkisi

Tablo 4. Günlükler Yoluyla Elde Edilen Nitel Araştırma Verilerinin Çözümlenmesi

\begin{tabular}{|c|c|c|c|c|c|c|}
\hline & $\begin{array}{l}\text { Birinci } \\
\text { Oturum }\end{array}$ & $\begin{array}{l}\text { İkinci } \\
\text { Oturum }\end{array}$ & $\begin{array}{l}\text { Üçüncü } \\
\text { Oturum }\end{array}$ & $\begin{array}{c}\text { Dördüncü } \\
\text { Oturum }\end{array}$ & $\begin{array}{l}\text { Beşinci } \\
\text { Oturum }\end{array}$ & $\begin{array}{l}\text { Altınc1 } \\
\text { Oturum }\end{array}$ \\
\hline $\begin{array}{c}\text { Öğrendiği } \\
\text { Deyimleri } \\
\text { yazanlar }\end{array}$ & $\begin{array}{c}\text { Ö-7, } \\
\text { Ö-11,Ö-14. }\end{array}$ & $\begin{array}{c}\text { Ö-1, Ö-2, } \\
\text { Ö-3,Ö-4, } \\
\text { Ö-7, Ö-8, } \\
\text { Ö-9, Ö-11, } \\
\text { Ö-14. }\end{array}$ & $\begin{array}{c}\text { Ö-1, Ö-2, } \\
\text { Ö-3, Ö-4, } \\
\text { Ö-5, Ö-6, } \\
\text { Ö-8, Ö-9, } \\
\text { Ö-10, Ö-11, } \\
\text { Ö-12, Ö-13, } \\
\text { Ö-14. }\end{array}$ & & & \\
\hline $\begin{array}{c}\text { Öğrendiği } \\
\text { Deyimleri } \\
\text { Anlamlarıyla } \\
\text { Birlikte } \\
\text { Yazanlar }\end{array}$ & $\begin{array}{c}\text { Ö-1, Ö-2, } \\
\text { Ö-3, Ö-4, } \\
\text { Ö-5, Ö-6, } \\
\text { Ö-8, Ö-9, } \\
\text { Ö-10, Ö-12, } \\
\text { Ö-13, Ö-15. }\end{array}$ & $\begin{array}{c}\text { Ö-5, Ö-6, } \\
\text { Ö-10, Ö-12, } \\
\text { Ö-13, Ö-15. }\end{array}$ & Ö-15. & & & \\
\hline $\begin{array}{c}\text { Öğrendiği } \\
\text { Atasözünü } \\
\text { Yazanlar }\end{array}$ & & & & $\begin{array}{c}\text { Ö-1, Ö-3, } \\
\text { Ö-4, } \\
\text { Ö-5, Ö-6, } \\
\text { Ö-7, Ö-8, } \\
\text { Ö-10, Ö-11, } \\
\text { Ö-12, Ö-13, } \\
\text { Ö-14, Ö-15. }\end{array}$ & $\begin{array}{c}\text { Ö-1,Ö-2, } \\
\text { Ö-3, Ö-4, } \\
\text { Ö-5, Ö-7, } \\
\text { Ö-8, Ö-9, } \\
\text { Ö-10, } \\
\text { Ö-11, } \\
\text { Ö-12, } \\
\text { Ö-13, } \\
\text { Ö-14, } \\
\text { Ö-15. }\end{array}$ & $\begin{array}{c}\text { Ö-1, Ö-2, } \\
\text { Ö-3, Ö-4, } \\
\text { Ö-5,Ö-6, } \\
\text { Ö-7, } \\
\text { Ö-8,Ö-10, } \\
\text { Ö-12, Ö-14, } \\
\text { Ö-15. }\end{array}$ \\
\hline $\begin{array}{c}\text { Öğrendiği } \\
\text { Atasözü ve } \\
\text { Deyimleri } \\
\text { Yazanlar }\end{array}$ & & & & Ö-2. & & \\
\hline $\begin{array}{l}\text { Yaratıcı Drama } \\
\text { Sürecindeki } \\
\text { Etkinliklerden } \\
\text { Söz Edenler }\end{array}$ & $\begin{array}{c}\text { Ö-2, } \\
\text { Ö-3, Ö-4, } \\
\text { Ö-5, Ö-9, } \\
\text { Ö-10, Ö-11, } \\
\text { Ö-14. }\end{array}$ & $\begin{array}{c}\text { Ö-1, Ö-3, } \\
\text { Ö-4, Ö-5, } \\
\text { Ö-6, Ö-7, } \\
\text { Ö-8, } \\
\text { Ö-10,Ö-11, } \\
\text { Ö-12, Ö-13, } \\
\text { Ö-14. }\end{array}$ & $\begin{array}{c}\text { Ö-1, Ö-2, } \\
\text { Ö-3, Ö-5, } \\
\text { Ö-6, Ö-7, } \\
\text { Ö-9, Ö-10, } \\
\text { Ö-12, Ö-13, } \\
\text { Ö-14. }\end{array}$ & $\begin{array}{c}\text { Ö-1, } \\
\text { Ö-3,Ö-5, } \\
\text { Ö-6, Ö-7, } \\
\text { Ö-12, Ö-13, } \\
\text { Ö-14, Ö-15. }\end{array}$ & $\begin{array}{c}\text { Ö-1, Ö-3, } \\
\text { Ö-4, Ö-6, } \\
\text { Ö-7, Ö-13, } \\
\text { Ö-14. }\end{array}$ & $\begin{array}{c}\text { Ö-2, Ö-3, } \\
\text { Ö-4,Ö-12, } \\
\text { Ö-13, Ö-14. }\end{array}$ \\
\hline $\begin{array}{c}\text { Yaratıcı Drama } \\
\text { Sürecine İlişkin } \\
\text { Tutumlarından } \\
\text { Söz Edenler }\end{array}$ & $\begin{array}{c}\text { Ö-3, Ö-4, } \\
\text { Ö-6, Ö-12. }\end{array}$ & $\begin{array}{c}\text { Ö-1, Ö-3, } \\
\text { Ö-9, Ö-11, } \\
\text { Ö-12. }\end{array}$ & $\begin{array}{c}\text { Ö-1, Ö-5, } \\
\text { Ö-7, Ö-10, } \\
\text { Ö-11, Ö-12, } \\
\text { Ö-14. }\end{array}$ & $\begin{array}{c}\text { Ö-1, Ö-3, } \\
\text { Ö-4, Ö-6, } \\
\text { Ö-7, Ö-8, } \\
\text { Ö-10, } \\
\text { Ö-11, Ö-12, } \\
\text { Ö-13, Ö-14. }\end{array}$ & $\begin{array}{c}\text { Ö-1, Ö-2, } \\
\text { Ö-3,Ö-4, } \\
\text { Ö-5, Ö-6, } \\
\text { Ö-9, Ö-10, } \\
\text { Ö-11, } \\
\text { Ö-12, } \\
\text { Ö-13. }\end{array}$ & $\begin{array}{c}\text { Ö-1, Ö-2, } \\
\text { Ö-3, Ö-4, } \\
\text { Ö-5, Ö-6, } \\
\text { Ö-8, Ö-9, } \\
\text { Ö-10, Ö-11, } \\
\text { Ö-12, Ö-13, } \\
\text { Ö-14. }\end{array}$ \\
\hline
\end{tabular}


Grafik 1. “Öğrendiğì” Deyimleri Yazanların Grafik Dağılımı

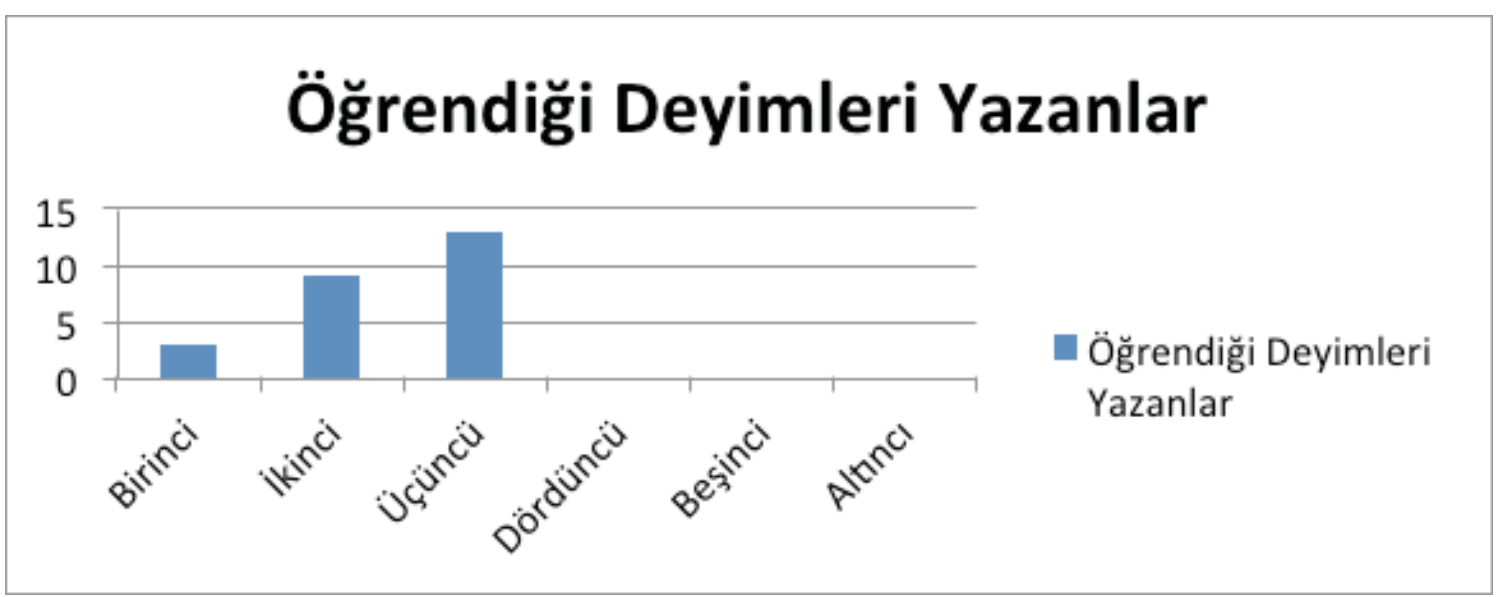

Projenin uygulanması aşamasında ilk üç oturum deyimlere ayrılmıştır. Grafik-1'de görüldüğü üzere birinci oturumda atölyede öğrendiği deyimleri yazanların sayısı 3 , ikinci oturumda 9, üçüncü oturumda da 13'tür. Öğrencilerin ilk üç oturumda öğrendiği deyimleri günlüklerine yazmaları aşağıdaki örneklerde verilmektedir:

Ö-11: “Bugün sabah okula geldiğimde öğretmenim bizi yukarıdaki atölyeye götürdü. Orada deyimlerin birkaçını gördük. Onlar: yaka silkmek, omuz silkmek, yüzü kızarmak, parmak ısırmak, burun kıvırmak, ses çıkarmamak."

Ö-7:“Bugün şu deyimleri gördük; “Küpünü Doldurmak, Kırk Dereden Su Getirmek, Tabanları Kaldırmak ve Çürük Tahtaya Basmak deyimlerini öğrendik.”

Ö-8: "Bugün bir sürü yeni deyim öğrendim. Bunlar: Kahve dövücüsünün hınk deyicisi, saman altından su yürütmek, bindiği dalı kesmek, ekmeğini taştan çıkarmak, dolap çevirmek.

Grafik 2. “Öğrendiğì” Deyimleri Anlamlarıyla Birlikte Yazanların Grafik Dă̆ılımı

\section{Öğrendiği Deyimleri Anlamlarıyla Birlikte Yazanlar}

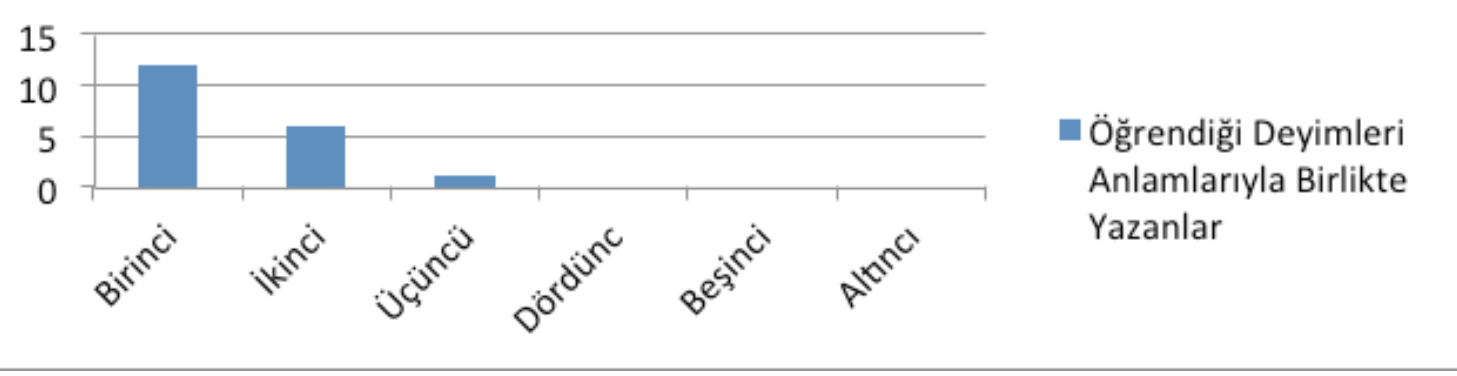

Grafik-2'de görüldüğü üzere, birinci oturumda öğrendiği deyimleri anlamlarıyla birlikte yazan öğrenci sayısı 12, ikinci oturumda 6, üçüncü oturumda da 1'dir. Öğrenciler öğrenilen deyimlerin anlamlarını şu şekilde yazmışlardır: 
Ö-10: “Canlandırdığımız deyimler ve anlamları burada: Kahve dövücüsünün hınk deyicisi anlamı bir şey yapmadan karşılık beklemek, ekmeğini taştan çıkarmak anlamı zor para kazanmak, dolap çevirmek anlamı gizli işler yapmak, saman altından su yürütmek anlamı gizli iş yapmak, bindiği dalı kesmek anlamı kendine zarar verme. İşte bu kadar.”

Ö-15: "Sevgili günlük, bugün bazı deyimleri ve anlamlarını öğrendik. Bunlar aşağıda yer aliyor:

- Çürük tahtaya basmak/ Anlamı: Düşünmeden hareket etmek, tehlikeli bir duruma düşmek.

- Küpünü Doldurmak/Anlamı: Haksızlık yaparak çok para kazanmak.

- Kırk Dereden Su Getirmek/ Anlamı: Çok uğraşmak.

Tabanları Kaldırmak/ Anlamı: Koşarak kaçmak.”

Grafik 3. "Öğrendiği” Atasözünü Yazanların Grafik Dă̆glımı

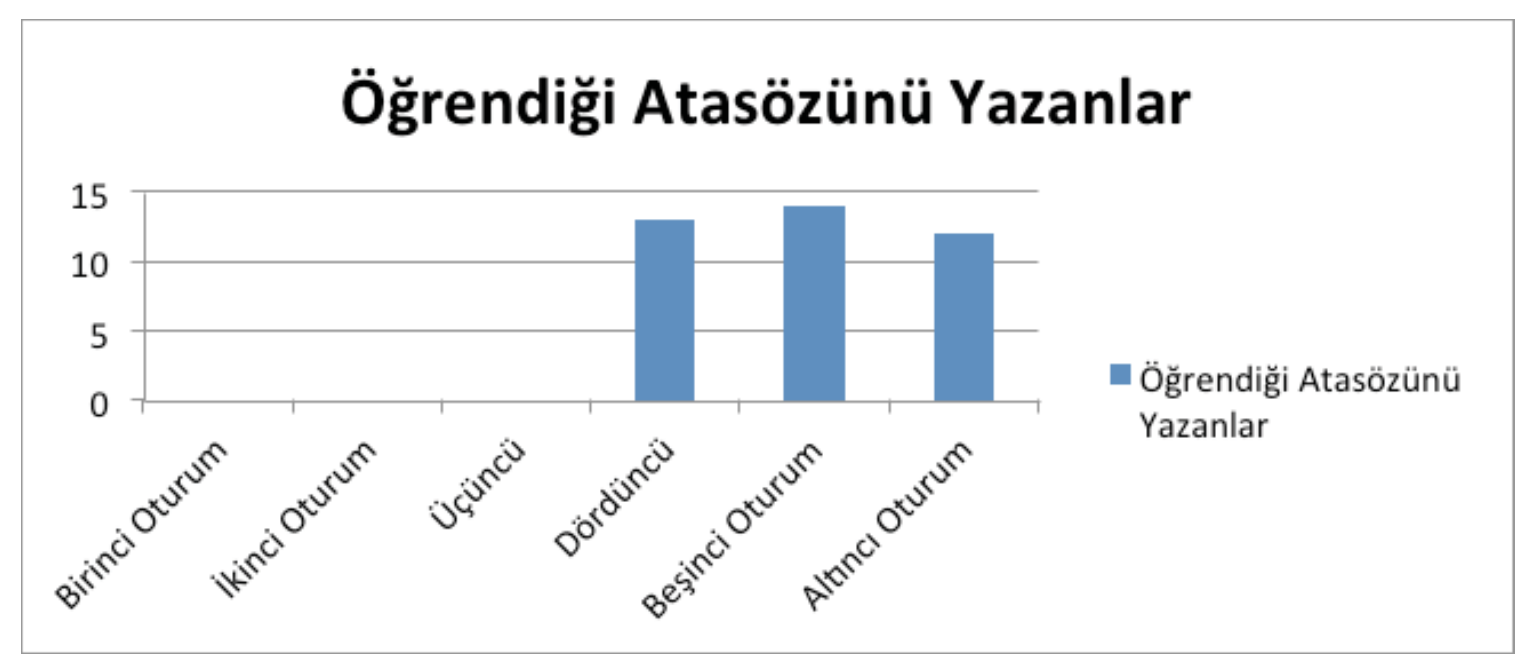

Projenin uygulanması aşamasında son üç oturum atasözlerine ayrılmıştır. Grafik 3'te görüldüğg̈ üzere dördüncü oturumda atölyede öğrendiği atasözlerini yazanların sayısı 13, beşinci oturumda 14 ve altıncı oturumda 12 'dir. Günlüklerde öğrenilen atasözlerini yazanlardan bazıları şu şekildedir:

Ö-4: “Bugün öğleden sonra üç atasözü öğrendik. Bunlar; Yerin Kulă̆ı Var, Akılsız Başın Cezasını Ayaklar Çeker, Davulun Sesi Uzaktan Hoş Gelir.”

Ö-10: “Merhaba, bugün yine birkaç atasözü öğrendik, oyun oynadık, canlandırma yaptık. Atasözleri : Kedi uzanamadı̆̆ ciğere pis dermiş, ava giden avlanır, bal tutan parmă̆ını yalar, altın yumurtlayan tavuk kesilmez."

Ö-2: “Bugün 3 atasözü ve bunlardan çok iyi besteler yaptık. Bu atasözleri şunlardır: Balık baştan kokar, kurda kuzu emanet edilmez, el elin eşeğini türkü söyleyerek arar.”

Ö-8: "Sevgili günlük, bugün yine bazı atasözlerini öğrendik. Bu sefer ü̈c taneydi: Balık baştan kokar, el elin eşeğini türkü söyleyerek arar, kurda kuzu emanet edilmez." 
Not: Ö-2 dördüncü oturumda atasözlerini yazd1ktan sonra daha önceki atölyelerde görmüş olduğu deyimleri de yazmıştır. Bu bağlamda atasözü ve deyimleri yazan 1 kişidir.

Grafik 4. Yaratıcı Drama Sürecindeki Etkinliklerden Söz Edenlerin Grafik Dağılımı

\section{Yaratıcı Drama Sürecindeki Etkinliklerden Söz Edenler}

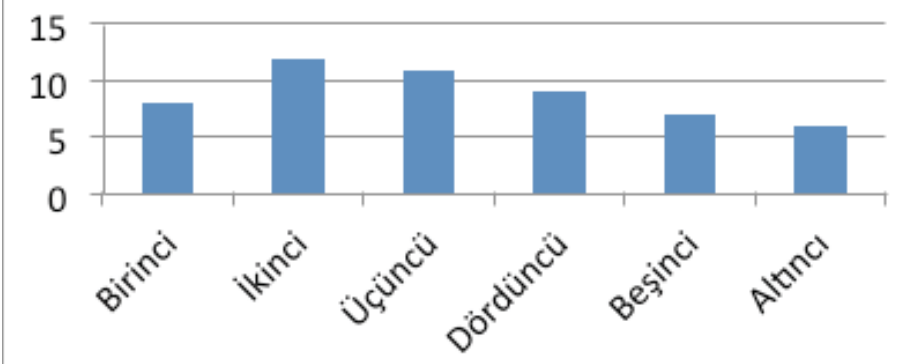

- Yaratıcı Drama Sürecindeki

Etkinliklerden Bahsedenler

Günlüklerde drama sürecindeki etkinliklerden söz eden öğrencilerin sayısı, Grafik 4’te de görüldüğü üzere, birinci oturumda 8 , ikinci oturumda 12 , üçüncü oturumda 11 , üçüncü oturumda 11, dördüncü oturumda 9, beşinci oturumda 7, altıncı oturumda 6'dır. Günlüklerde yaratıcı drama sürecindeki etkinliklerden söz edilen örnekler aşağıda verilmiştir:

Ö-9: “Oyun oynadık. Deyimlerle ilgili resim yaptık, pantomim avcısı diye bir oyun oynadık, doğaçlama yaptık.”

Ö-3: "ve de bir sürü oyun oynadık. Bunlar; Davul zurna 1,2,3 ve pandomim avcısiydı. Ve

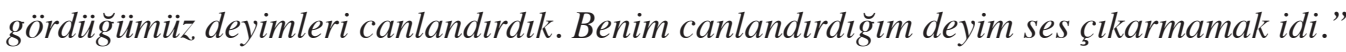

Ö-10: “Bugün atölyede davul zurna bir, iki, üç oynadık. Ve yeni bir oyun öğrendim, adı pantomim avclst."

Ö-6: “Öğleden sonra atölyede oyunlar oynadık. Canlandırmadaki grubum Ali, Selim, Mert, Ben, Timur, Ünal'dr."

Ö-13: “Bugün öğretmen bizi gruplara ayırdı. Üç atasözünü canlandırdık. Bence en güzel bizimki oldu."

Ö-12: “Bugün atölyede ilk önce oyun oynadık. Bir atasözünü bedenimizle arkadaşımıza anlatmaya çalıştık. Ondan sonra bize kağıt verildi, bir de resim. O resimdeki şeyleri kartona sözcük halinde yazdık, ondan sonra grup olup yazdı ğımı sözcüklerden beş tanesini seçtik. Ö̆̆retmen bize atasözünü verdi. Biz de seçtiğimiz beş sözcükle doğaçlama yaptık.”

Ö-5: "Bugün atölyede yine deyimleri işledik. Güzel geçti. 2 tane oyun oynadık. En çok sevdiğim derelerden su toplamaktı."

Ö- 14:"Bugün de her zamanki gibi dramada doğaçlama, resim ve hikaye yazdık. Bugün 4 yeni deyim öğrendim ama bugün bu deyimleri ve anlamlarını söylemicem. Bugün çok heyecanlı bir yarış yaptık. Dayanamıyorum söylicem. "40 dereden su getirdik, tabanları kaldırdık, çürük tahtaya bastık ve küpü doldurduk.” 
Grafik 5. Yaratıcı Drama Sürecine İlişkin Tutumlarından Söz Edenlerin Grafik Dağılımı

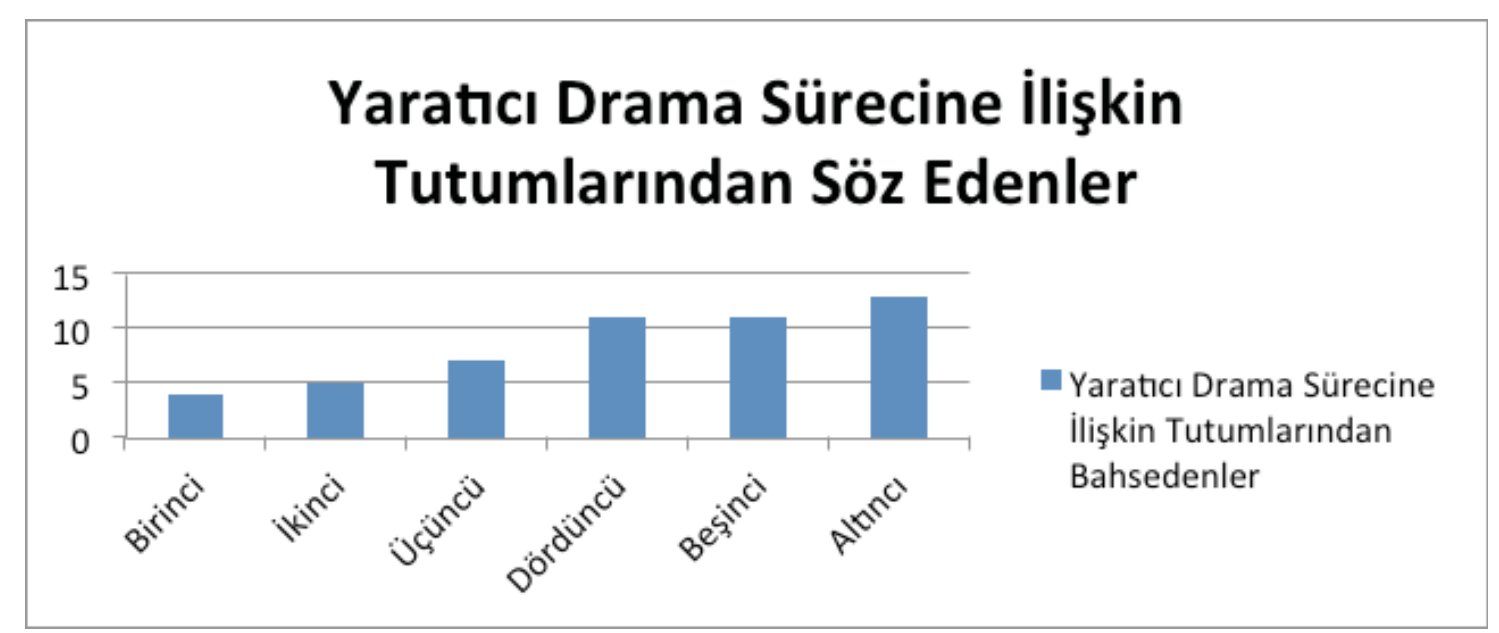

Grafik 5'te görüldüğü üzere yaratıcı drama sürecine ilişkin tutumlarından söz eden öğrenci say1sı birinci oturumda 4 , ikinci oturumda 5 , üçüncü oturumda 7 , dördüncü oturumda 11 , beşinci oturumda 11 ve altınc1 oturumda 13 'tür.

Ö-1: “Artık senle bir daha görüssemeyeceğiz ama yine de olsun, altı gün senle e ğlendik. Bugün son bir kere atölyeye gittik. Yine çok ĕ̆lendik.”

Ö-2: "En sevdiğim oyunlar vardı. Bunlar; top atmaca, şarkı besteleme, davul yapma, büyük kağıda resim çizme, Kulaktan kulağa oynama.”

Ö-3: "Bir de en çok "Pantomim Avcısı" adlı oyunu sevdim. Güzel bir gün geçirdim."

Ö-3: “Bugün son günlü̆̆̈̈m çünkü artık drama yapmayacă̆ız. Bugün ĕ̆lendik. Grupça

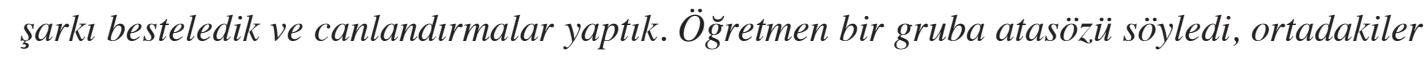
bağırıp atasözünün karşı tarafa geçmesini engelliyordu."

Ö-4: “Bu son atölyeye gelişimizde, bu dramada çok e ğlendim. Keşke bitmeseydi. Kendimize şarkı yaptık ve onu canlandırdık. Çok eğlenceliydi. Bütün dramaları de ğerlendirmek gerekirse bütün dramalar çok harikaydı.”

Ö-5: “Bu son günlü̆̆̈̈̈m, drama bana hem yeni şeyler ögrretti hem de ĕglendirerek eskileri düşünmemi sağladı. En çok rol yapmaktan hoşlandım.”

Ö-6: "Bugün atölyede işimiz bitti. Aslında azıcık üzüldüm. Ama yine de yeni atasözleri ögrendik.”

Ö-7: “Atasözü firlatma oyununu çok sevdim.”

Ö-8: “Bu etkinliğin devam etmesini çok isterdim. Ama ne yazık ki bitti. Bugün çok güzeldi”

Ö-9: “Bugün çok e ğlendik. Gerçekten güzel bir tanesi şu; balık baştan kokar. Keşke dramaya devam etsek."

Ö-10: “Tabuya benzeyen çok güzel, ĕ̆lenceli bir oyun oynadı.”.

Ö-11: “Bugün drama derslerimizin son günü, ben dramayı çok sevdim. Ve severek öğrendim. Diyorum ki drama derslerine devam edelim. Drama dersi süreci boyunca bir sürü atasözü, deyim öğrendim.” 
Ö-12: "Oyunlar da oynadık yine. Çok eğlendik. Canlandırmalar da yaptık. Zamanımız çok güzel geçti.”

Ö-13: "En çok sevdiğim canlandırmalar oldu. Sizin de yapmanızı tercih ederim."

Ö-14: "En çok sevdiğim kırk dereden su getirmekti."

Öğrenciler, sürecin başında verilen açık uçlu sorularla oluşturulmuş başarı testine yukarıda yer verdikleri deyim ve atasözlerine ilişkin bir şeyler yazamazken süreçte yazdıkları günlüklerde bu deyim ve atasözlerine yer vermişlerdir. Grafik 1, 2 ve 3'ün sonunda yer alan öğrenci yorumlarında öğrencilerin öğrendikleri deyimleri ve atasözlerini tam ve doğru yazdıkları görülmüştür. Bunda yaratıcı drama sürecinin hazırlık- 1sınma aşamasında yer verilen etkinliklerin katkısının olduğu söylenebilir. Grafik 4 ve Grafik 5'te öğrenciler deyim ve atasözlerini yaratıcı drama sürecindeki etkinliklerde kullandıklarını ifade etmişlerdir. Bu ifadelerden yola çıkarak öğrencilerin süreçte aktif oldukları, öğrendikleri bilgileri farklı bir yere transfer edebildikleri, öğrendiklerinden yola çıkarak yeni bir ürün ortaya çıkarabildikleri, verilen deyimleri doğaçlamalarda birleştirerek özgün bir bütün oluşturdukları görülmektedir. Bu bağlamda yaratıcı drama yönteminin öğrencilerin üst düzey düşünme becerilerine katkı sağladığı söylenebilir. Yaratıcı dramanın yapısı gereği öğrencilerin kendilerini daha rahat ifade edebildikleri ve süreç boyunca aktif oldukları bir ortam sağladığı görülmektedir. Öğrenciler, oyunlar oynadıklarını, şarkılar söylediklerini ve doğaçlamalar yaptıklarını belirtmiştir. Bu bağlamda öğrencilerin bu etkinliklerle Türkçe öğretiminin alt öğrenme alanı olan dinleme ve konuşma becerilerini doğal bir öğrenme ortamında gerçekleştirdikleri görülmektedir.

\section{Sonuç ve Öneriler}

Yaratıcı dramanın yöntem olarak kullanıldığı "Yaratıcı Dramanın İlkokul Öğrencilerinin Sözvarlığını Geliştirmede Bir Yöntem Olarak Kullanılması” çalışmasının sonucu olarak; katılımcıların ön test ve son test puanları arasında pozitif yönde anlamlı bir fark olduğu anlaşılmıştır. Katılımcıların sürecin başında kendilerine uygulanmış olan başarı testinden aldıkları puanların ortalaması 25,83 olarak, aynı başarı testine süreç sonunda verdikleri yanıtlarla topladıkları puanlarının ortalamaları 92,25 olarak hesaplanmıştır. Katılımcıların puanları, Wilcoxon İşaretli Sıralar Testi’yle karşılaştırıldığındaysa, ön test- son test puanları arasında pozitif yönde anlamlı bir farklılık olduğu ortaya çıkmıştır. Bu bulgular 1şığında yaratıcı dramanın yöntem olarak kullanıldığı Türkçe öğretimi sürecinde öğrencilerin sözvarlığını geliştirmede başarılı olduğu söylenebilir.

Türkçe Dersi Öğretim Programı’nın en önemli amaçlarından biri Türkçeyi doğru, etkili ve güzel kullanan bireyler yetiştirmek ve öğrencinin sözvarlığının zenginleştirilmesini sağlamaktır. Bu becerilerin geliştirilmesi için öğrencinin ezberleyerek değil, süreçte aktif olduğu, öğrenci merkezli öğretim anlayışıyla yapılandırılan, öğretmenin sınıfta öğrenciyi aktif duruma getirecek yöntemlere gereksinim duyulmaktadır. Bu bağlamda yaratıcı drama ile Türkçe Dersi Öğretim Programı'nın amaçlarının örtüştüğü görülmektedir. Öğrenciler yaratıcı drama sürecinde yaparak yaşayarak öğrenmeler gerçekleştirmektedir. Öğrencilerin aktif olduğu yaratıcı drama sürecinde kalıcı öğrenmeler gerçekleşmekte, öğrenciler yaşantılarından yola çıkarak edindikleri bu bilgileri günlük yaşamda kullanabilmektedirler.

Türk halk kültürünün önemli yapı taşı olan atasözleri ve deyimlerin Türkçe sözvarlığında önemli bir yere sahip olduğu söylenebilir. Türkçe Dersi Öğretim Programı’nın öğrenme alanlarının alt başlıklarında yer alan "Sözvarlığını Geliştirme" başlığı altında öğrencinin sözvarlığını 
geliştirecek etkinliklere yer verilmesi önerilmektedir. Bu çalışmada yaratıcı drama, öğrencilerin sözvarlığını geliştirmede bir yöntem olarak kullanılmıştır. Bu çalışmanın bulguları doğrultusunda, yaratıcı dramanın Türkçe öğretimi sürecinde öğrencilerin sözvarlığını geliştirmede bir yöntem olarak kullanılmasının bilişsel anlamda başarılı olduğu ortaya konmuştur. Bulgular katılımcılardan toplanan günlüklerle nitel olarak desteklenmiştir.

Nitel araştırma verileri analiz edilmiş ve somut işlemler döneminde olan ilkokul öğrencilerinin soyut olarak gördüğü deyimler ve atasözlerini süreçte kullanılan etkinliklerle somutlaştırabildiği günlüklerindeki temalarda görülmektedir. 15 öğrencinin 14'ünün bütün oturumların sonunda öğrendiği deyimleri ve atasözlerini tam ve sıralı bir şekilde yazdığı görülmektedir. Bu bağlamda yaratıcı dramanın hazırlık sürecinde yer alan etkinliklerle öğrencilere deyimler, atasözleri ve anlamları kavratılmıştır. Bulgulardan yola çıkarak hazırlık aşamasının öğrencilerin atasözleri ve deyimleri tam ve sıralı söylemelerinde etkili olduğu söylenebilir. Yaratıcı dramanın ikinci aşaması olan canlandırmalarda atasözleri ve deyimlerin anlamlarına ilişkin etkinlikler gerçekleştirilerek öğrencilerin yaşantılarından yola çıkarak atasözleri ve deyimleri günlük yaşamlarına aktarmaları sağlanmaya çalışılmıştır. Türkçe öğretiminin etkinlik alanları olan "dinleme", "okuma", "konuşma", "yazma" becerilerini geliştirmeye yönelik yaratıcı drama sürecinde yer alan etkinliklerle birbirini bütünleyen etkinliklerle canlandırma aşaması desteklenmiş ve Türkçe Dersi Öğretim Programı’nın amaçlarına katkıda bulunulmuştur. Yaratıcı dramanın üçüncü aşaması olan değerlendirme aşaması ile birlikte öğrencilerin kültürün geçmişten günümüze yansıması olan atasözleri ve deyimleri kullanmalarına ilişkin farkındalıkları arttırılmaya çalışılmıştır. Öğrenciler her oturumun sonunda yazmış oldukları atasözleri ve deyimleri son oturumda değerlendirdiklerinde: "Bir sürü atasözü ve deyim öğrendik." yorumlarında bulunmuştur. Aksan'a (2006) göre; "bugün canlılı̆̆ını koruyan atasözlerimizin 2000 dolayında olduğu ve deyimlerimizin ise günden güne yenileri eklenerek 7000 dolaylarına eriştiği düşünülmektedir.” bilgisini aktardığımda çok şaşırmışlar ve bunların günlük yaşamda kullanılması gerektiği sonucuna sordukları sorularla ulaşmış oldukları gözlenmiştir.

Bulguların yorumlanmasında kullanılan görsellerden de anlaşılacağı üzere öğrenciler oturumların sonunda yaratıcı drama sürecine ilişkin görüşlerini yazmışlar ve yaratıcı dramanın bitmemesine ilişkin görüşlerde bulunmuşlardır. Öğrencilerin yaratıcı drama sürecine ilişkin tutumlarında sıklıkla yer alan ifade: "Bugün atölyede çok eğlendim." olmuştur. Bu bağlamda yaratıcı dramanın yöntem olarak kullanıldığı bu çalışmada öğrencilerin süreçten zevk alarak derse istekli katılımların sağlandığı söylenebilir.

İlkokul öğrencilerinin sözvarlığını geliştirmede yaratıcı dramanın kullanılmasının, bireylerin süreç içerisinde öğrendiği deyimler ve atasözlerini anlamlandırmada etkili bir öğretim yöntemi olduğu söylenebilir.

Söz konusu sonuçlardan hareketle ilkokuldaki Türkçe öğretimine ve sonraki araştırmalara yönelik olarak aşağıdaki öneriler getirilebilir:

1. Türkçe derslerinde öğrencilerin sözvarlığını geliştirmede yaratıcı drama yönteminden yararlanılmalıdır.

2. Türkçe derslerinde yaratıcı drama yönteminin farklı konu ve becerilere etkisi araştırilmalidir.

3. Benzer çalışmalar farklı sınıf düzeylerinde ve farklı çalışma gruplarıyla yapılmalıdır. 


\section{Kaynaklar}

Adıgüzel, Ö. (2006). Yaratıcı drama kavramı, bileşenleri ve aşamaları. Yaratıcı Drama Dergisi, 1(1), 203-222.

Adıgüzel, Ö. (2010). Tamer Levent’e Armağan Yaratıcı Drama 1999-2002 Yazılar. Ö. Adıgüzel (Ed.), Niçin Yaratıcı Drama? (s. 255-262). Ankara: Naturel Yayincilık.

Adıgüzel, Ö. (2013). Eğitimde Yaratıcı Drama. Ankara: Pegem A Yayıncılık.

Aktaş Arnas, Y. Cömertpay B. ve Sofu, H. (2007). Altı yaş grubu çocukların dil kullanımına yaratıcı dramanın etkisi. Yaratıcı Drama Dergisi, 1 (3-4), 7-26.

Aykaç, M. (2011). Türkçe öğretiminde çocuk edebiyatı metinleriyle kurgulanan yaratıcı drama etkinliklerinin anlatma becerilerine etkisi. Yayımlanmamış Doktora Tezi. Ankara Üniversitesi.

Bağcı, H. (2010). İlköğretim 5. sınıf öğrencilerinin atasözleri ve deyimleri algılama düzeyi. Türklük Bilimi Araştırmaları, XXVII, 91-110.

Büyüköztürk, Ş. (2005). Sosyal Bilimler İçin Veri Analizi El Kitabı İstatistik, Araştırma Deseni, SPSS Uygulamaları ve Yorum. Ankara: Pegem A Yayınclık.

Büyüköztürk, Ş., \& Çakmak, Kılıç, E., \& Akgün, Ö. E., \& Karadeniz, Ş., \& Demirel, F. (2008). Bilimsel Araştırma Yöntemleri. Ankara: Pegem A Yayınclık.

Demirci, S. ve Baş, B. (2016). İlkokul 3. sınıflarda söz varlığının geliştirilmesi üzerine bir eylem araştırması. Milli Eğitim Dergisi, 210, 215-235.

Erdoğan, T. (2013). The effect of creative drama method on pre-service classroom teachers' writing skills and attitudes towards writing. Australian Journal of Teacher Education, 38 (1), 44-61.

Gönen, M. (2010).Tamer Levent'e Armağan Yaratıcı Drama 1999-2002 Yazılar. Ö. Adıgüzel (Ed.),Çocuk Eğitiminde Drama Yönteminin Kullanılması, (s. 34-42). Ankara: Naturel Yayıncılık.

Heathcote, D. (1984). Collected writings. London: Hutchinson.

Karateke, E.(2006). Yaratıcı Dramanın İlköğretim II. Kademede 6. Sinıf Öğrencilerinin Yazılı Anlatım Becerilerine Olan Etkisi. Yayımlanmamış Yüksek Lisans Tezi, Hatay: Mustafa Kemal Üniversitesi.

Kavcar, C. (1999). Edebiyat ve Eğitim. Ankara: Engin Yayınevi.

Kaya Güler, İ. (2008). İlköğretim dördüncü sınıf Türkçe dersinde yaratıcı dramanın etkililiği. Yayımlanmamış Yüksek Lisans Tezi, 19 Mayıs Üniversitesi.

Kırmızı, F. S. (2008). Türkçe dersinde yaratıcı drama yöntemine dayalı yaratıcı yazma çalışmalarının yazmaya yönelik tutuma etkisi. Yaratıcı Drama Dergisi, 4 (7), 51-68

Mert, E. L. (2009). Anadili eğitim ve öğretim sürecinde sözvarlığı belirleme çalışmalarının önemi ve "deyim" kazandırmaya yönelik etkinlik önerileri. Adıyaman Üniversitesi Sosyal Bilimler Enstitüsü Dergisi, 2 (2), 83-93.

San, I. (1995). Yaratıc1lık ve eğitim, Milliyet Sanat Dergisi, Ankara.

Sever, İ. (2002). Prof. Dr. İnci San’a Armağan Yaratıcı Drama 1985-1998 Yazılar. Ö. Adıgüzel (Ed.),Yaratıcı Dramanın Eğitsel Boyutları, (s.113-122). Ankara: Naturel Kitap Yayın Dağıtım.

San, İ. (2010). Tamer Levent'e Armağan Yaratıcı Drama 1999-2002 Yazılar. Ö. Adıgüzel (Ed.),Türkiye'de Eğitimde Yaratıcı Drama Çalışmalarının Gelişsimi, (s.18-28). Ankara: Naturel Yayıncılık.

Sever, S. (2011). Türkçe Öğretimi ve Tam Öğrenme. Ankara: Anı Yayınc1lık.

Tuğrul, B.(2003). Drama ve ögrrenme-öğretme. Ali Öztürk (Ed.), Çocukta Yaratıcllk ve

Drama, içinde. Anadolu Üniversitesi Yayınları Nu: 1488: Eskişehir.

Türnüklü, A. (2001). Eğitimbilim Alanında Aynı Araştırma Sorusunu Yanıtlamak İçin Farklı

Araştırma Tekniklerinin Birlikte Kullanılması. Eğitim ve Bilim, 26(120), 8-13.

Yıldırım, A. \& Şimşek, H. (2013). Sosyal bilimlerde nitel araştırma yöntemleri. Ankara:

Seçkin Yayıncılık.

Stowe, A. (2001). Using drama to improve creative writing. Retrieved December 5, 2012, http://www.ntrp.org. uk/sites/all/documents/Stowe.pdf. 


\section{Ek 1: Atölye Plan Örneği (Birinci Oturum)}

Ders: Türkçe

Konu: Deyimler

Grup: 4. Sınıf Öğrencileri

Süre: 180 dakika

Kullanılan Yöntem/Teknikler: Yaratıcı drama/ Donuk imge, doğaçlama, rol oynama, küçük grupla yapılan doğaçlama.

Araç- Gereçler: Renkli kartonlar, jel boya, beyaz bant, belirlenen duygu durumlarının yazılı olduğu kağıtlar, zarf, küçük kağıtlar.

Mekan: Özel Çankaya Anafartalar İlkokulu Drama Dersliği

\section{Kazanımlar:}

- Konuşmasında sözvarlığını kullanır.

- Günlük yazar.

- Duygu, düşünce, bilgi ve izlenimlerini resim kullanarak görselleştirir.

- "Parmak 1sırmak" deyiminin anlamını bilir.

- "Yaka silkmek" deyiminin anlamını bilir.

- “Yüzü kızarmak" deyiminin anlamını bilir.

- "Burun kıvırmak" deyiminin anlamını bilir.

- “Omuz silkmek" deyiminin anlamını bilir.

- “Ses çıkarmamak” deyiminin anlamını bilir.

Süreç

\section{A- Hazırlık-Isınma}

\section{Etkinlik (Pantomim Avı)}

Katılımcılar arasından gönüllü bir kişi pantomim avcısı olur. Geriye kalan diğerleri de pantomim sanatçıları olur. Pantomim avcısı pantomim sanatçılarını yakalamaya çalışır. Pantomim sanatçıları ebeye yakalanmamaya çalışırlar. Pantomim sanatçıları vurulmadan önce bir mimikle donarlarsa ebe onları yakalayamaz.

Diğer pantomim sanatçıları arkadaşlarını kurtarmak için donan pantomim sanatçısının önüne gelip aynı mimiği yaparlar ve tekrar oyuna dahil olurlar. Oyun daha sonra iki ebeyle oynanır.

\section{Etkinlik (Duygunu yansit 1, 2, 3 (...) )}

Oyuna başlamadan önce katılımcılar arasından gönüllü bir ebe seçilir. Ebeye "mekânda bir duvarın önünde, yüzü duvara bakar şekilde ve arkasındaki oyuncuları görmeyecek şekilde durması" söylenir. Katılımcılardan da, ebeden 5-10 metre uzaklıkta bir çizgide durmaları istenir. Lider ebeye sırasıyla "şaşmak, bıkmak, utanmak, beğenmemek, aldırmamak, kabullenmek" durumlarını verir. Ebeden gözlerini kapaması, duvara elini vurmasını ve vururken "Duygunu yansıt 1-2-3 (şaşırmak)" demesi istenir. Ebenin arkası dönükken katılımc1lar ebeye doğru hareket eder. Ebe önünü döndüğünde söylediği duyguyu yapmayan ve hareket eden olursa oyundan dışarı çıkar. 


\section{Ara Değerlendirme}

Çember olunur. Lider katılımcılara ilk oyunda pantomim sanatçısı olduklarında neler hissettiklerini ve hangi duygu durumlarına girdiklerini sorar. İkinci oyunda hangi duygu durumlarını yansıtırken zorluk çektikleri üzerine konuşulur. Katılımcılardan, ikinci oyunda yer alan duygu durumlarının neler olduğunu çemberdeki A4 kağıtlarına her birine bir duygu gelecek şekilde yazmaları istenir. Duygu durumlarının yazıldığı kağıtlar duvara asılır.

\section{Etkinlik}

Katılımcılar çember olur. Lider katılımcılardan birden altıya kadar sırayla saymalarını ister. Birler, ikiler, üçler, dörtler... yan yana gelecek şekilde üçlü grup oluşturulur.

Lider her gruba renkli karton, boya kalemleri ve her bir gruba bir tane deyim verir. Deyimler; "parmak 1sırmak”, “yaka silkmek”, yüzü kızarmak”, "burun kıvırmak”, “omuz silkmek”, "ses çıkarmamak" tır. Lider gruplardan verilen deyimlerin resimlerini yapmalarını ister. Gruplar resimlerini bitirdikten sonra katılımcılar çembere gelir.

Lider yapılan resimleri çemberde ilk resim tekrar başa gelene kadar katılımcıların incelemelerini ister. Gruplardan, resimlerinin daha önce duvara asılan duygu durumlarından hangisini yansıttığını bularak onun altına yapıştırmaları istenir.

\section{B- Canlandirma}

\section{Etkinlik}

Çember olunur. Lider grubu ikiye ayırır. Grupları A ve B olarak adlandırır. Gruplar karşı karşıya gelir. Lider iki grubun ortasına bir çizgi çizer. Lider, grupları sırasıyla çizgi üzerine çağıracağını söyler. Çizgi üzerine gelen gruplar liderin verdiği deyime uygun donuk imgeler oluştururlar. Lider A grubu dediği anda A'lar çizgiye gelir. Lider; "Parmak 1sırmak" der ve katılımcılar parmak ısırmak deyimine uygun donuk imge oluşturup beklerler. Lider, katılımcılara karışık olarak; "Kimsin?", "Neredesin?", "Ne zaman oldu?", "Nasıl oldu?", "Ne oldu?" sorularını sorar. Katılımcilardan gelen yanıtları duvarda asılı olan deyimlerin altına yazar. Lider; "B grubu" der ve B'ler çizgiye gelir. Lider; "Yaka silkmek" der ve katılımcılar yaka silkmek deyimine uygun donuk imgeler oluşturup beklerler. Lider, katılımcılara karışık olarak; "Kimsin?", "Neredesin?”, "Ne zaman oldu?", "Nasıl oldu?", "Ne oldu?" sorularını sorar. Katılımcılardan gelen yanitları duvarda asılı olan deyimlerin altına yazar. Lider sırayla "Yüzü kızarmak", "Burun kıvırmak", "Omuz silkmek", "Ses Çıkarmamak” deyimlerini gruplara uygular ve gelen yanıtları ilgili deyimlerin altına yazar.

\section{Etkinlik}

Çember olunur. Katılımcılar birden altıya kadar sayar. Birler, ikiler, üçler...altılar yan yana gelecek şekilde üçerli gruplar oluşturulur. Lider duvarda asılı olan deyimlerin anlamlarını, resimlerini ve yazılanları her gruba dağıtır. Gruplara bunları kullanarak doğaçlamalarını hazırlayabileceklerini söyler.

Her doğaçlamanın ardından ara değerlendirme alınır. Bu deyimlerin başka hangi durumlarda kullanılabileceği üzerine katılımcılarla konuşulur.

\section{C- Değerlendirme}

\section{Etkinlik}

Sürecin sonunda lider öğrencilere birer zarf verir. Zarfın arkasına her katılımcının adını yazmasını ister. Her katılımcının bir zarfı olur.

Lider bugün öğrendikleri deyimleri verilen renkli küçük kağıtlara yazıp zarflara koyulmasını ister. Bu zarflar son atölyeye kadar sınıfın bir köşesine yapılan söz dağarcığı ağacında asılı kalacaktır. 